\title{
Drought and vegetation analysis in Tarsus River Basin (Southern Turkey) using GIS and Remote Sensing data
}

\author{
Celalettin Duran ${ }^{1}$
}

\begin{abstract}
In this study, the effects of topographic variables on drought and vegetation in dry season have been examined. Distributions of dry conditions in Tarsus River Basin were derived using the NDVI, NDMI indexes and LST (Land Surface Temperature) from landsat8 image bands. There is large difference in elevation in the study area. Local climatic conditions are formed under the influence of altitude and morphological structure. Narrow and deep valleys in the topography create more moderate temperature/moisture conditions and are the main distribution area of tall forest vegetation. High radiation in the highest plateau system and, extreme temperature/moisture values led short-lived herbaceous vegetation to spread. Due to high insolation/temperature and restricted marine affect, establishment of scrub vegetation can be observed both in mid-elevation and south-sloping plateau of the study area. Anthropogenic agricultural fields form the land surface with the potential of high temperature/evapotranspiration rate in harvesting periods. Broadleaf plant species spread in areas close to the base of the valley stream. Plantation forest has been created in areas of near-shore sand dunes and very small delta (marsh).

Variability in topography also increases the width of the combination of factors that shape the vegetation. This also enables the number of taxa to increase and unusual taxa to co-exist.
\end{abstract}

Keywords: Moisture; Tarsus River Basin; Temperature; Topography; Vegetation

\section{Introduction}

The most important factor shaping the vegetation in Mediterranean-type climate zone is the summer drought period. The variation in topography strongly influences local climatic conditions. Micro-climate regions have led to plant species diversity and an increase in locally distributed taxa (Duran, 2012; 2013).

Mediterranean-type climate limits the plant life in midsummer. This type of climate is not convenient for high tree formations to grow owing to severe drought prevailing in summer sessions (Erinc, 1977). In the regions that have humid soil conditions, there are mostly woody

\footnotetext{
${ }^{1}$ Ph.D., Kastamonu University, Faculty of Science and Letters, Department of Geography, cduran@kastamonu.edu.tr
} 
species whereas on the arid regions there seem to be mostly herbaceous species (Fernandez et al. 2001). Dry conditions vary according to the topographic features.

Past climate changes in accordance with the conditions offered by the topography has led to plant migration (Atalay, 1994; Duran, 2013). Biodiversity has the highest level in forests, thickets, and landscapes where the juxtaposition of semi-open areas and bare areas make up the mosaic. Natural environment factors are heterogeneous. Excess of endemic plant species is due to severely fragmented habitat created by relief located close to the sea (Montgolfier, 2005).

The Central part of Taurus Mountains of southern Turkey is rich in terms of topographical variety and karstic landforms. Karst topography has a strong influence on the development of soil types and vegetation formations (Efe, 2014). The ecological importance of the topography is fully stressed by altitude, aspect and climate (Atalay et al. 2014). Bolkar Mountains within the central part of Taurus Mountains have rugged terrain, deep canyon valleys and changing altitude conditions. Therefore, it has more than 1,500 different plant species and 300 of them endemic species (Gemici, 1992).

Satellite images are an important source of data to obtain information about the Earth's surface without direct contact (Rhinane et al. 2012). Nowadays, vegetation and climatic variables can be easily determined using remote sensing methods. Landsat 8 images can also estimate relationships between the abundance of vegetation and surface temperature/moisture, evapotranspiration and drought (Yuan and Bauer, 2007; Mallick et al., 2008; Roy et al. 2014).

It has been found that there is a stronger linear relationship between the Land Surface Temperature (LST) and the Normalized Difference Vegetation Index (NDMI). With the change of seasons from summer to autumn, the linear correlation relationship between the LST and NDMI has been gradually lowered (Le-xiang and Hai-shan, 2008). A large number of water- and climaterelated applications, such as drought monitoring, are based on spaceborne. Multiple regression analysis has revealed that during the beginning and the end of the growing season, solar radiation is the predominant factor driving the correlation between the LST and Normalized Difference Vegetation Index (NDVI) (Karnieli et al. 2010).

\section{Material and Methods}

\subsection{Study area}

The study area is limited to the basin formed by the Tarsus stream and its effluents in southern Turkey. Streams formed in the south and south-east facing slopes of Bolkar Mountains mass meet at Berdan Dam Lake. The main stream separates from the dam lake, known as Tarsus stream, and pours into the Mediterranean passing through the town of Tarsus. 
Duran, C. (2015). Effects on drought and vegetation of topography in the Tarsus River Basin (Southern Turkey). International Journal of Human Sciences, 12(2), 1853-1866. doi:10.14687/ijhs.v12i2.3370

The highest point of the study area is Medetsiz Hill, which also forms the summit of Bolkar Mountains mass $(3524 \mathrm{~m})$. The basin area is of approximately $2136 \mathrm{~km}^{2}$. Watershed boundaries are located between $36^{\circ} 44^{\prime} 58^{\prime \prime}-37^{\circ} 26^{\prime} 00^{\prime \prime}$ north latitude and $34^{\circ} 13^{\prime} 22^{\prime \prime}-34^{\circ} 59^{\prime} 40^{\prime}$ east longitude (Fig.1).

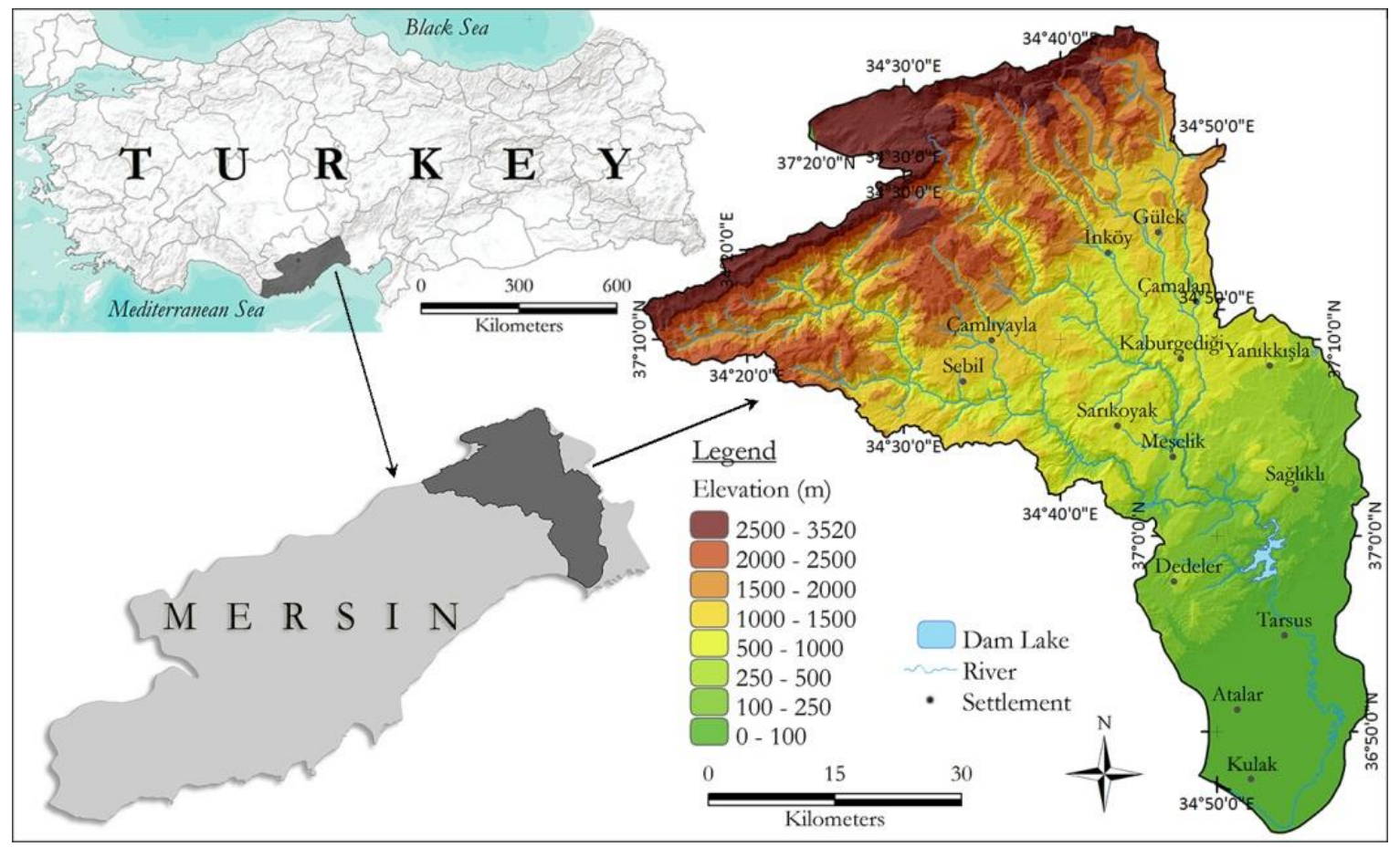

Figure 1. Location of the study area

\subsubsection{Geology/Lithology}

There are geological formations belonging to different periods in the Tarsus River Basin. The geological structure of the area is constituted of limestone from Paleozoic and Mesozoic periods and covers units from Tertiary and Quaternary periods (Fig. 2a).

The Bolkar Mountains mainly consist of Permo-Carboniferous limestones (Gemici, 1995). They have been welded together with the folding and uprising of Alp orogenic belt. Karst formations and fluvial erosion have accelerated during the Quaternary Pluvial period. Deep valleys situated in the southern slopes of Bolkar Mountains are a result of this eroding and karstification (Gurses et al. 1996). Orographic precipitation has played an important role in the ruggedness of terrain, which is composed of limestone in middle and high elevations. The elevation difference between the base and the slopes of the valleys can reach up to $1500 \mathrm{~m}$ in some parts of the region.

\subsubsection{Geomorphology}

The geomorphologic structure of the basin has been shaped by the structural features of the Taurus Mountains belt. The river has played an important role in the morphological 
Duran, C. (2015). Effects on drought and vegetation of topography in the Tarsus River Basin (Southern Turkey). International Journal of Human Sciences, 12(2), 1853-1866. doi:10.14687/ijhs.v12i2.3370

configuration within the basin boundaries. Two important affluents of the stream are Cehennemdere and Kadincik creek. These affluents have deeply eroded their river beds. The morphological structure is composed of denudational (erosional) surfaces, valley floors, valleys and gorges, karst forms, deltaic plain and coastal dunes. There are a large number of dolines in high flat areas. Temporary lakes, which become dry in summer, form in some of these dolines. Karagol $(2590 \mathrm{~m})$ and Ciniligol $(2660 \mathrm{~m})$, bearing the traces of glaciation process, are located within this highest area (Fig. 2b). In addition, there are two major straits opened by Pozanti Creek and Tarsus River. Different plant taxa spread on this variable land surface.

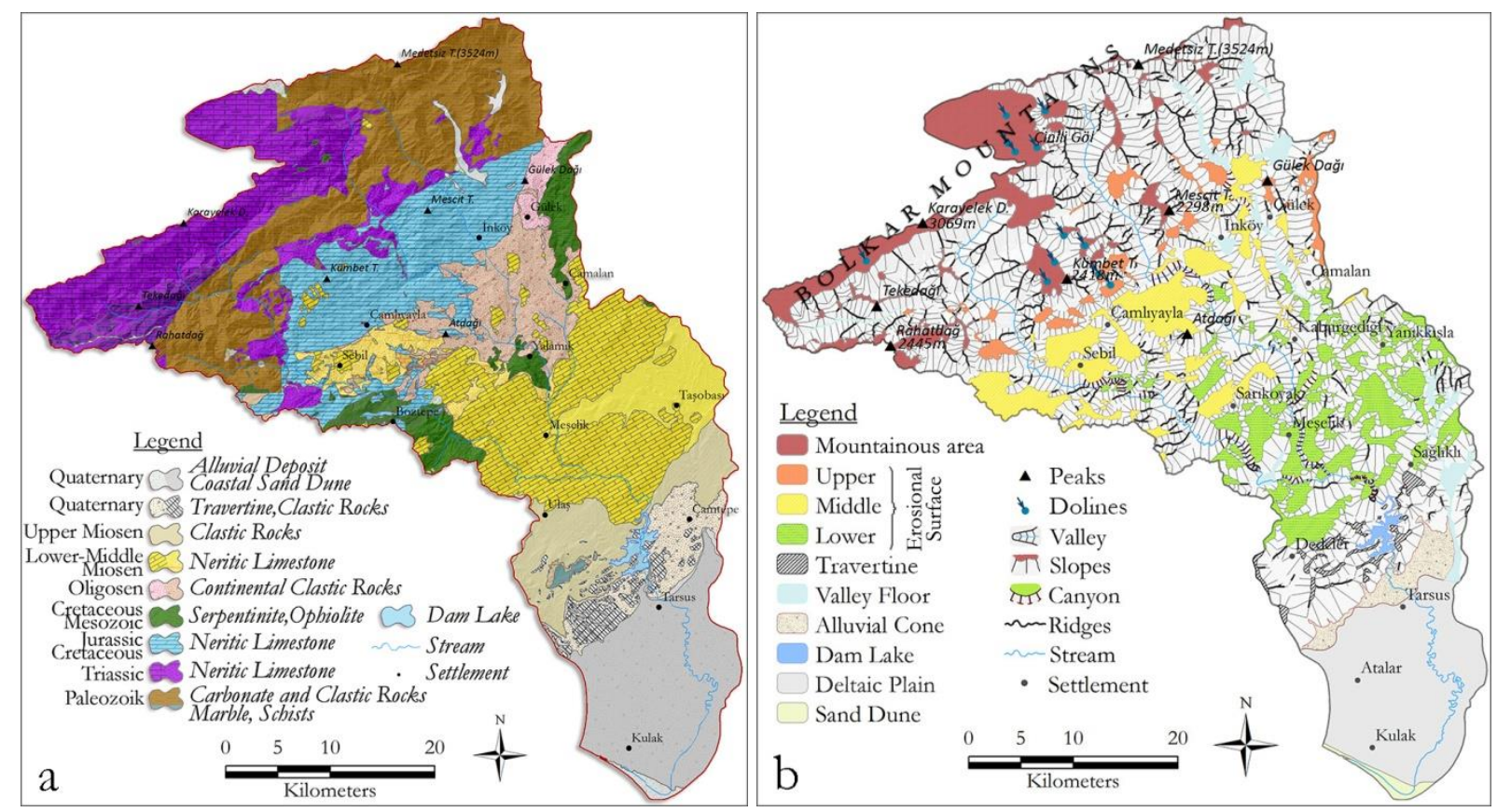

Figure 2. a. Geology/Lithology (MTA, 2013) b. Geomorphology of the study area

\subsubsection{Plant cover}

Wooded areas are dense on the slopes of the valley. Along the slopes near the valley floor Calabrian pine (Pinus brutia) communities are located between 500-1100 meters (-1600). Between 1100-1700 meters the black pine (Pinus nigra ssp. pallasiana), cedar (Cedrus libani) and fir (Abies cilcica ssp. cilicica) forests grow and expand. They are either pure or mixed. In the destroyed areas and extreme climate conditions of the upper elevation, local communities of Juniper (Juniperus spp.) or its individual species could be observed (Fig. 3).

Hygrophilous species are found in the valley bottom. The highly qualified sycamore (Platanus orientalis) communities (Fig. 8) with hophornbeam (Ostrya carpinifolia) community are remarkable especially between 500-1000 meters. In this section, there are hornbeam (Carpinus orientalis ssp. orientalis), hazelnuts (Corylus avellana var. avellana), chinaberry (Styrax officinalis), walnut (Juglans regia), 
Duran, C. (2015). Effects on drought and vegetation of topography in the Tarsus River Basin (Southern Turkey). International Journal of Human Sciences, 12(2), 1853-1866. doi:10.14687/ijhs.v12i2.3370

alder (Alnus orientalis var. orientalis and var. pubescens). Yew (Taxus baccata) yellow flowering dogwood (Cornus mas), wild dogwood (Cornus sanguinea ssp. cilcica) ash (Fraxinus ornus ssp. cilcica) et al. are common (Gemici et al., 1996).

The humid microclimate prevailing in the deep valleys has allowed the development of specific vegetation types and gallery forest peculiar to Black Sea coast. With the upper limit of the forest, subalpine vegetation, which resists the dominance of low thorny bushes (kamefit) such as Onobrychis cornuta, Astragalus spp, can be observed. Within this belt, which is mostly composed of rocky-stony areas, Gramineae meadows are located locally. Although less in amount, Cyperaceae hygrophyte turbiyer and meadows also characterize the Alpine zone. Advanced kasmofit communities on the cliffs are common (Gemici et al., 1996).

Hard-leaved Water-wise-Scrub species that have adapted to dry conditions in summer can be observed in locations with high temperatures and low humidity. Different types of shrubs are as in the following: Carob (Ceratonia siliqua), olives (Olea europaea var. sylvestris), Kadincik bush (Flueggea anatolica), kermes oak (Quercus coccifera), sumac (Rhus coriaria), turpentine (P. terebinthus), Grecian strawberry tree (Arbutus andrachne), laurel (Laurus nobilis), redbud (Cercis siliquastrum), fig (Ficus carica), buckthorn (Rhamnus alaternus), phllyrea (Phillyrea latifolia), daphnia (Daphne sericea), bean trefoil (Anagyris foetida), broom (Spartium junceum), fontanesia (Fontanesia philliraeoides), capers (Capparis spinosa).

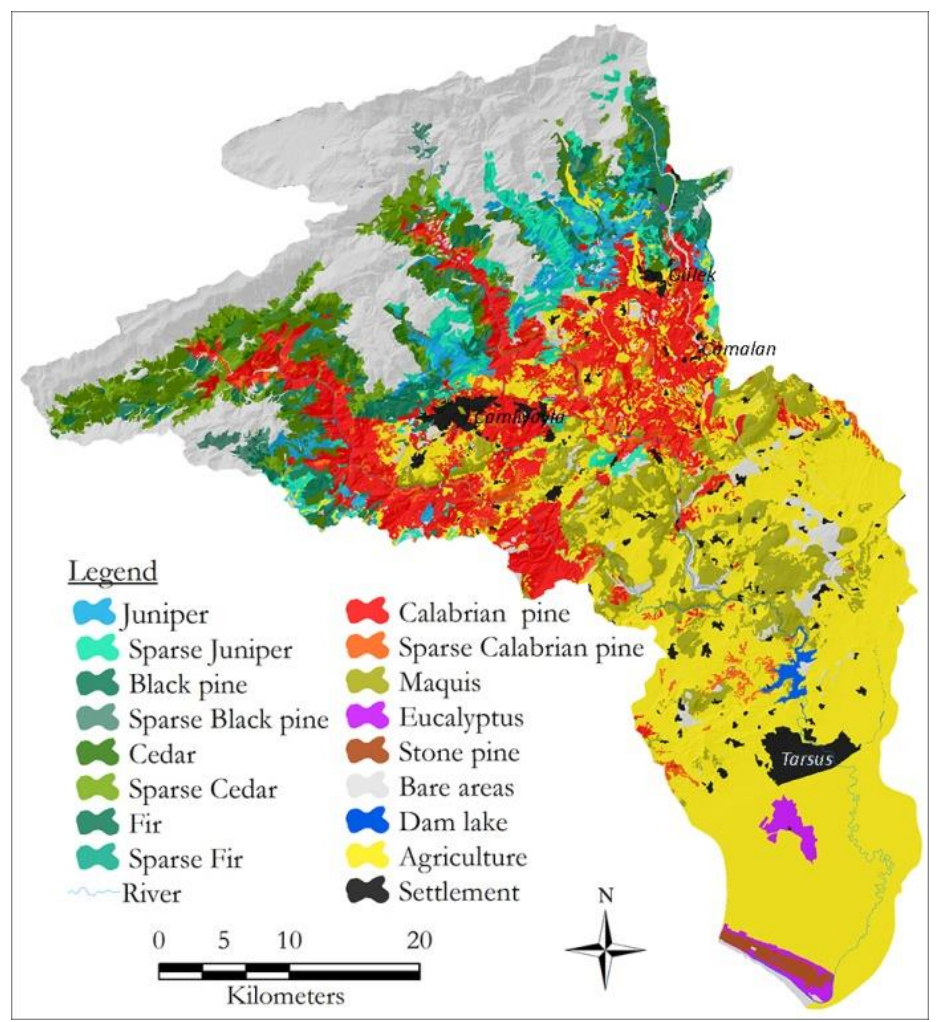

Figure 3. Plant cover and land use of the study area 
Duran, C. (2015). Effects on drought and vegetation of topography in the Tarsus River Basin (Southern Turkey). International Journal of Human Sciences, 12(2), 1853-1866. doi:10.14687/ijhs.v12i2.3370

\subsection{Data/Materials}

Landsat 8 images (Row/Path: 34/175-176) dated on August 8 and 22, 2014 at 16:06 have been used with a resolution of 30 meters for using bands in this research. The data acquisition date has a highly clear atmospheric condition, and the image has been acquired through the USGS Earth Resource Observation Systems Data Center (URL 1).

Digital Elevation Model (DEM, $10 \mathrm{~m}$ ) has been used for physiographic characteristics. Maps belonging to study area (Forest map (GDF, 2013), Geology map (MTA, 2013 scaled 1/100.000)) and Topography map (scaled $1 / 100.000$ and $1 / 25.000)$ ) have been derived.

The all images and maps are projected in UTM (Universal Transverse Mercator, WGS1984, Zone 36N). Photography and plants samples have been taken from different topographic locations.

\subsection{Methods}

To identify vegetation, thermal and moisture anomalies were used the bands from Landsat 8 OLI (B4, B5, B6) and TIRS (B10, B11).

\subsubsection{Estimation of NDVI and NDMI $\left(4^{\text {th }}, 5^{\text {th }}\right.$ and $6^{\text {th }}$ bands from Landsat 8$)$}

NDVI (Normalized Difference Vegetation Index): This index is used more for the density of green vegetation in remote sensing. Unhealthy or sparse vegetation reflects more visible light and less near-infrared light. The index is done using the reflection from the near-infrared and red band $\left(5^{\text {th }}\right.$ and $4^{\text {th }}$ band respectively for Landsat 8$)$. The normalized difference vegetation index values have been calculated using the following classic formula:

$$
\text { NDVI= (NIR-RED)/(NIR+RED) }
$$

NDMI (Normalized Difference Moisture Index): This index contrasts the near-infrared (NIR, band 5), which is sensitive to the reflectance of leaf chlorophyll content to the shortwave-infrared (SWIR, band 6), which is sensitive to the absorbance of leaf moisture. Values higher than 0.1 are symbolize high humidity level. Low values (close to -1) symbolize low humidity level (an indicator for dryness). NDMI has been calculated using the following equation

$$
N D M I=(N I R-S W I R) /(N I R+S W I R)
$$

\subsubsection{Derivation of Land Surface Temperature $\left(10^{\text {th }}\right.$ and $11^{\text {th }}$ bands from Landsat8)}

The LST were derived from the corrected Landsat8 TIR sensors $(10.62-12.51 \mu \mathrm{m})$. Landsat TIRS were rescaled to the Top of Atmosphere (TOA) reflectance and/or radiance using radiometric rescaling coefficients provided in the product metadata file (MTL file). The MTL file 
also contains the thermal constants needed to convert TIRS data to the at-satellite brightness temperature (URL 2).

Conversion formula from DN to Radiance (from MTL file):

$$
L_{\lambda}=M_{L}^{*} Q_{\text {cal }}+A_{L} \quad\left(L_{\lambda}=0.0003342 * D N+0.1\right)
$$

Conversion to At-Satellite Brightness Temperature (into degrees Celsius)

TIRS band data was converted from the spectral radiance to at satellite brightness temperature using the thermal constants provided in the metadata. The conversion formula is as in the following;

$$
T_{\mathrm{B}}=K_{2} / \operatorname{Ln}\left(K_{1} / L_{\lambda}+1\right)-273,15 \text { where, }
$$

$T_{\mathrm{B}}$ is effective at-satellite temperature in $\mathrm{K}, L_{\lambda}$ is spectral radiance in $\mathrm{W} /\left(\mathrm{m}^{2}\right.$ ster $\left.\mu \mathrm{m}\right)$; and $K_{1}$ and $K_{2}$ constants: band-specific thermal conversion constant from the metadata $K_{1}=774.89, K_{2}=1321.08$ (for B10), $K_{1}=480.89, K_{2}=1201.14$ (for B11) used in this study

Calculation of Land Surface Emissivity (LSE)

The LSE was calculated by utilizing NDVI method (Sobrino et al. 2004).

$$
\varepsilon=\left(0.004 * \mathrm{P}_{\mathrm{v}}\right)+0.986 \text { where, }
$$

$\varepsilon$ : emissivity value, $\mathrm{P}_{\mathrm{v}}$ : Vegetation proportion

$$
\mathrm{P}_{\mathrm{v}}=\left[\left(\mathrm{NDVI}-\mathrm{NDVI}_{\min }\right) /\left(\mathrm{NDVI}_{\max }-\mathrm{NDVI}_{\min }\right)\right]^{2}
$$

Estimation of Land Surface Temperature (LST)

The emissivity corrected land surface temperatures $\left(S_{t}\right)$ were computed as follows (Weng et al. 2004; Artis \& Carnahan, 1982).

$$
S_{\mathrm{t}}=T_{\mathrm{B}} /\left(1+\left(\lambda^{*}\left(T_{\mathrm{B}} / \rho\right)\right) * \ln (\varepsilon)\right) \text { where, }
$$

$\lambda=$ wavelength of emitted radiance (for which the peak response and the average of the limiting wavelengths $(\lambda=11.5 \mu \mathrm{m})$ (Markham \& Barker, 1985)), $\rho=b \mathrm{x} c / \sigma\left(1.438 \times 10^{-2} \mathrm{~m} \mathrm{~K}\right), \sigma=$ Boltzmann constant $\left(1.38 \times 10^{-23} \mathrm{~J} / \mathrm{K}\right), b=$ Planck's constant $\left(6.626 \times 10^{-34} \mathrm{Js}\right)$, and $c=$ velocity of light $\left(2.998 \times 10^{8} \mathrm{~m} / \mathrm{s}\right)$

\subsubsection{Distribution of dry conditions on terrain surface within dry season}

It is dry conditions in midsummer that have shaped the vegetation in the Mediterranean-type climate regions. It has been calculated with the total to reveal the distribution of these conditions of LST, NDVI and NDMI (of August).

Distribution of dry conditions on terrain surface within dry season has been calculated using the following formula:

Dry Conditions $=$ NDVI + NDMI + LST

NDVI, NDMI and LST were subdivided as following (Table 1): 
Duran, C. (2015). Effects on drought and vegetation of topography in the Tarsus River Basin (Southern Turkey). International Journal of Human Sciences, 12(2), 1853-1866. doi:10.14687/ijhs.v12i2.3370

Table 1. Categorical classification of NDVI, NDMI and LST (4 class)

\begin{tabular}{llllll}
\hline NDVI & Class & NDMI & Class & LST & Class \\
\hline Too dense & 1 & Humid & 1 & Cool & 1 \\
Dense & 2 & Sub-humid & 2 & Warm & 2 \\
Sparse & 3 & Semi-dry & 3 & Hot & 3 \\
Bare area & 4 & Dry & 4 & Very hot & 4 \\
\hline
\end{tabular}

A map showing distribution of the surface area dominated by dry conditions has been obtained by collecting the factors composed of four different classes. Based on the total of these classes; the regions where dry conditions are the lowest are represented by number 3. Regions where dry conditions are the highest are represented by number 12 .

\section{Results and Discussions}

\subsection{NDVI and NDMI of the study area}

Obtained from Landsat $4^{\text {th }}, 5^{\text {th }}$ and $6^{\text {th }}$ bands dated August 8 and 22, NDVI and NDMI images describe the differences in topography. In the northern and eastern slopes of deep valleys, vegetation and humidity intensified (Figure $4 \mathrm{a}, \mathrm{b}$ ). Very sparse vegetation can be observed in the highest plateau system.

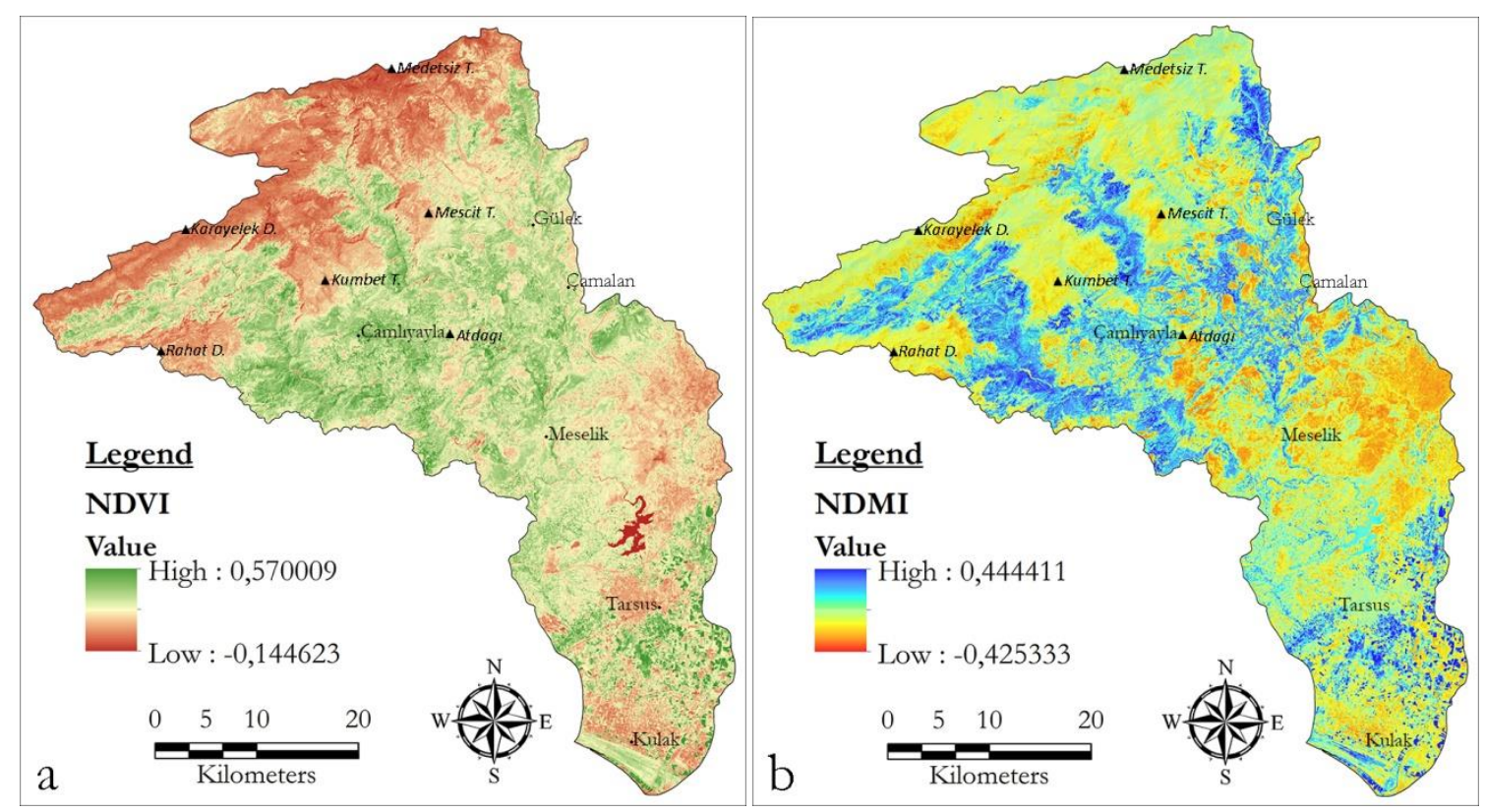

Figure 4. a) NDVI and b) NDMI of the study area 
Duran, C. (2015). Effects on drought and vegetation of topography in the Tarsus River Basin (Southern Turkey). International Journal of Human Sciences, 12(2), 1853-1866. doi:10.14687/ijhs.v12i2.3370

\subsection{LST of the study area}

Surface temperature affects the evapotranspiration potential. In dry season, due to an increase in surface temperature, the evapotranspiration rate increases. Water moving away from land surfaces with high surface temperature causes the growth of dry habitat. The continuation of drought would lead to the spread of unproductive areas. The classification of these sensitive regions within the topography may play a key role for the measures to be taken.

The highest plateau of the study area -higher than $2000 \mathrm{~m}$, is covered with a blanket of snow in the extreme cold winter season. Snow melts fast in south-facing surfaces due to high insolation in summer.

Temperatures are high in south-facing slopes, bare surfaces where plants cannot grow, in high lands where there are rock blocks and in open surfaces facing south used for agricultural purposes (surrounding of dam lake) in the lower and medium altitude (Fig. 5).

The bottoms of the deep valleys and NE facing slopes have more moderate (warm and cool) temperature conditions. Temperature is lower in forest plantation on Delta and in the surfaces covered with agricultural plantation, while it is higher in bare fields that have been harvested.

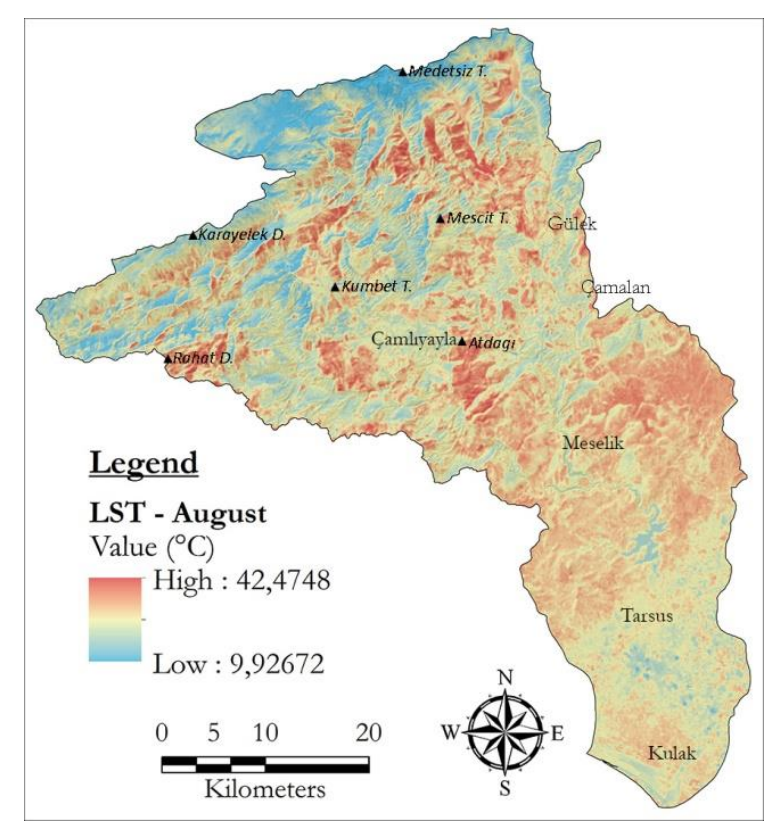

Figure 5. LST-August 2014 of the study area

\subsection{Relationships between Topography and Dry Conditions}

The distribution of the dry conditions in the study area has been calculated with the total and the value is as in Fig. 6 of the LST, NDVI and NDMI in (month of August). The topography of the study area seems to play an important role in changing the temperature/humidity and dry conditions. There is vegetation type that is compatible with this difference in topography. 
Duran, C. (2015). Effects on drought and vegetation of topography in the Tarsus River Basin (Southern Turkey). International Journal of Human Sciences, 12(2), 1853-1866. doi:10.14687/ijhs.v12i2.3370

Particularly, forest formation, maquis and herbaceous vegetation are distributed according to the micro-climate variability in topography (Fig. 6).

Vegetation can be classified on the basis of ecological features as dry conditions. In the highest plateau where extreme hot and cold conditions are effective, sparse herbaceous with short vegetation period has enabled the vegetation to spread.

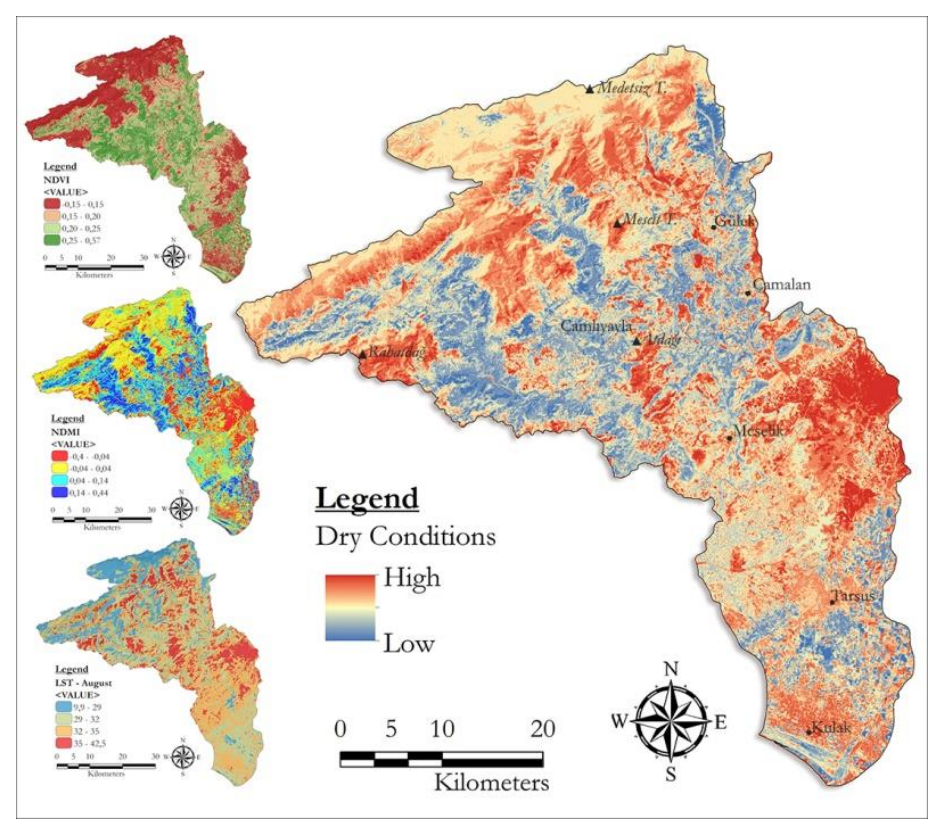

Figure 6. Combination map of NDVI, NDMI and LST

The Tarsus River is fed by the waters from the Bolkar Mountains situated at its north. Rare plant communities can be observed on the slopes of the valley widening and narrowing in some parts, from the highest point to the Dam Lake (Fig. 3). Escarpments and crags can be observed along the slopes of the valley. While pine dominates crags, broad-leaved species take their place on the escarpments. Broad-leaved species show faster and better development in the loose soil. On bare rocky crags with physiological depth, coniferous species are the dominant plant species.

There is a temperature difference between the upper parts and the lower parts of the valley. Accordingly, bottom parts of the slope are colder at night and frost can be seen (Akman, 1990). Cold air can accumulate in the pit area because it is heavier and more intense than the hot air is. Heat changes vary at certain parts of the valley and in particular on the valley floor. Such hollow spaces are cold at night and hot during the day. These areas are called frost pockets. In the frost pockets of Kadincik valley (Fig. 7), ordering between the Calabrian pine and black pine depends on elevation changes (Sengun and Duran, 2008). This segment is characterized by Calabrian pine on higher slopes (dominant), a mixture of black pine grows on land near the lower slopes.

North facing slopes of deep valleys caused by NW-SE trending rivers remain less under the influence of Insolation effect. In dry periods, burning and drying effects of the sun's rays are 
Duran, C. (2015). Effects on drought and vegetation of topography in the Tarsus River Basin (Southern Turkey). International Journal of Human Sciences, 12(2), 1853-1866. doi:10.14687/ijhs.v12i2.3370

limited in this area. It creates a sheltered area for the conservation of the humidity. The interior parts of the deep valleys are areas with temperate climates (Fig. 8). Certain parts of narrow and deep canyon valleys extending to the highest plateau from Dam Lake create shaded views.

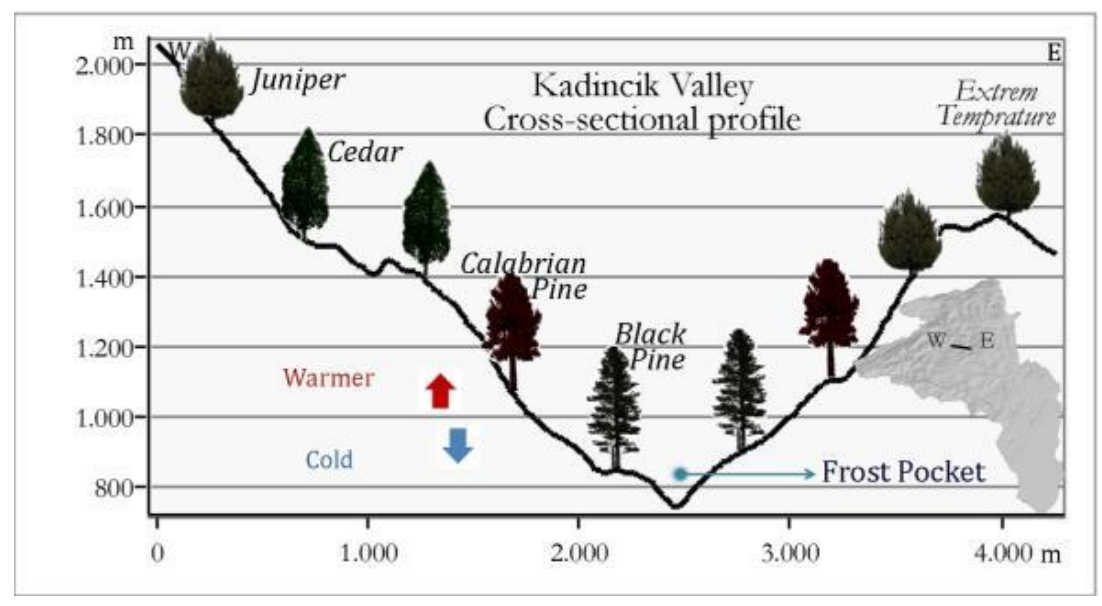

Figure 7. In the frost pocket of Kadınck valley, Anatolian black pine is seen at lower parts while Turkish red pine (Calabrian pine) is seen at higher parts.

Some of the species in the study area are accepted as relict and endemic species. In terms of narrow range plants, these valleys host local species such as Ajuga postii, Echinops mersinense ve Flueggea anatolica. Flueggea anatolica is a relict species and dates back to the Tertiary period, and its habitat is a very limited area between the valley floor and the slopes of Kadincik valley (Fig. 9).

Landscape plays an important role in the structure of vegetation and its other characteristic properties. Warm microclimate rises inside the valleys because of the "marine affect"

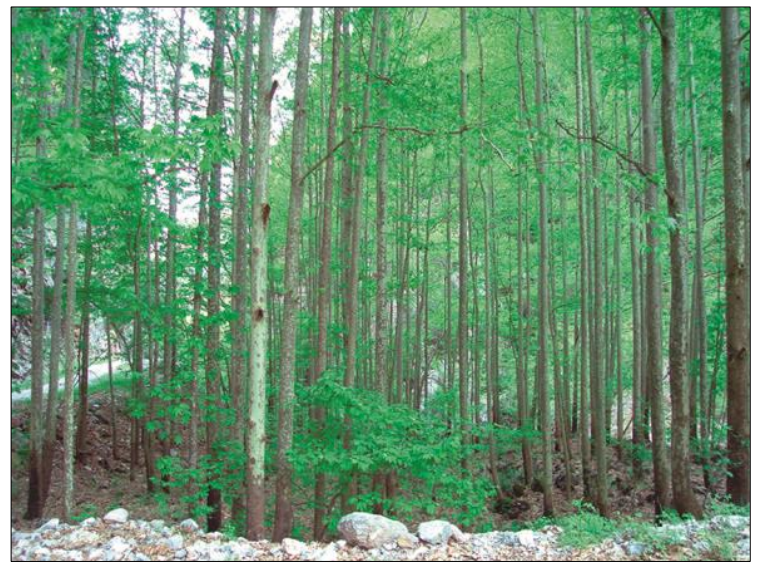

Figure 8. A view from bodied sycamore tree whose valley floors are extremely smooth due to humid conditions.

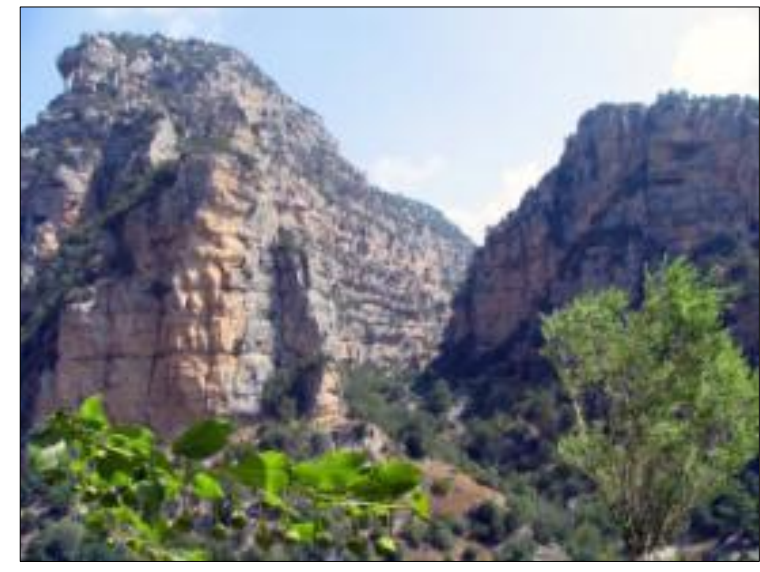

Figure 9. Slopes of Kadincik canyon are very steep and jagged. Relict Kadincik bushes are on the sheltered slopes close to valley floor. 


\section{Conclusions}

In this study, indicator variables (density of vegetation, moisture and surface temperature) for dry conditions on local topography have been examined. Using Lansat 8 image bands $\left(4^{\text {th }}, 5^{\text {th }}, 6^{\text {th }}\right.$, $10^{\text {th }}$ and $11^{\text {th }}$ bands) NDVI, NDMI indexes and LST have been derived. These data have been combined to estimate the dry conditions in the study area.

In Mediterranean climate regions, prevailing heat waves coincides with the vegetation period. Besides hot temperatures, the decrease in rainfall is in this term, too. The dry conditions prevent the plant growth in there. Character of growing media has been estimated using distribution of dry conditions on terrain surface.

Large part of the study area lies on mountainous zone climate in sense of Mediterranean's marine characteristics and an increase in the altitude towards north. Vegetation groups show a distribution according to the summer drought tolerance. The dry conditions play a major role in the geographical distribution of vegetation. In the humid regions in which there is lower insolation, there seem to be very tall vegetation. Vegetation in the characteristic of xerophytic is common in the regions in which there is less rainfall and more evaporation.

The water, which is the lifetime source of all beings, is the preliminary condition to carry out the vital functions. The access to water for terrestrial ecosystems has an important role on the distribution of species.

South-sloping plateaus in the study area are surfaces dominated by dry conditions. In these areas, herbaceous and shrub vegetation are common. In the form of protecting the moisture of soil, they cover the soil. The plant species being a member of maquis have adapted to dry conditions morphologically.

Along the routes that deep valleys lie, woody vegetation and tall trees spread thanks to more moderate climatic conditions and effective use of water by soil. In the slopes of valleys that have different views and elevations, distribution of the species varies in accordance with tolerance towards heat/humidity. The wider combination of different environmental variables in topography there is, the more variety there is in plant species diversity and vegetation types.

Along with open surfaces that increase evapotranspiration, the main material is limestone, which is effective in fending off shallow soil and water and increases the severity of drought conditions.

The method can be used for define the vegetation in regions with the Mediterranean-type climate. 
Duran, C. (2015). Effects on drought and vegetation of topography in the Tarsus River Basin (Southern Turkey). International Journal of Human Sciences, 12(2), 1853-1866. doi:10.14687/ijhs.v12i2.3370

\section{References}

Akman, Y. 1990. Climate and Bio-climate, Palme publications, engineering series: 103, Ankara. Turkey (In Turkish).

Artis, D.A. and Carnahan, W.H., 1982. Survey of emissivity variability in thermography of urban areas, Remote Sensing of Environment, 12, 13-329.

Atalay, I. 1994. Vegetation Geography of Turkey, Ege University publication, Izmir. Turkey (In Turkish).

Atalay, I., Efe, R. and Ozturk, M. 2014. Effects of topography and climate on the ecology of Taurus mountains in the Mediterranean region of Turkey, Procedia-Social and Behavioral Sciences, 120, 142-156

Duran, C. 2012. Distribution of forest areas according to physiographic features in Mersin province (South of Turkey), J-HumanSciences.com, 9(1), 1-19. (In Turkish).

Duran, C. 2013. The role of mountainous areas on plant diversity of Turkey, BIBAD, 6(1): 72-77. (In Turkish).

Efe, R. 2014. Ecological properties of vegetation formations on karst terrains in the central Taurus mountains (Southern Turkey), Procedia-Social and Behavioral Sciences, 120, 788-805

Erinç, S., 1977. Vegetation Geography, Istanbul University publications no.92, Istanbul. Turkey (In Turkish).

Fernandez-Illescas, C.P.; Porporato, A.; Laio, F.; Rodriguez-Iturbe, I. 2001. The Ecohydrological Role of Soil Texture in a Water-Limited Ecosystem, Water Resources Research 37(12), 2863-2872.

Gemici, Y., 1992. Flora and vegetation of Bolkar mountains (The central part of Taurus mountains). Ege University research project no:1988/011, 318 s. Izmir. (In Turkish).

Gemici, Y., 1995. Three important areas on the Bolkar mountains for the in-situ conservation of plant biodiversity, The Karaca Arboretum Magazine, 3(2), 55-79, Ankara. (In Turkish).

Gemici, Y., Gurses, M. K., Yllmaz, E., 1996. The value of Kadincik valley and its surrounding as a nature conservation area. Journal of $D O A, 2,91-111$, Tarsus. (In Turkish).

Gurses, M. K., Gemici, Y., Ozkurt, N., Gulbaba, A. G., Ozkurt, A., Tufekci, S., 1996. Investigation on plant biodiversity among black pine (Pinus nigra Arn. var. pallasiana Schneid.) populations on the Bolkar Mountains, Journal of DOA, 2, 49-69, Tarsus. (In Turkish).

Karnieli, A., Agam, N., Pinker, R. T., Anderson, M., Imhoff, M. L., Gutman, G. G., Panov, N. \& Goldberg, A. (2010). Use of NDVI and land surface temperature for drought assessment: merits and limitations, Journal of Climate, 23(3), 618-633.

Mallick, J., Kant, Y., \& Bharath, B. D. (2008). Estimation of land surface temperature over Delhi using Landsat-7 ETM+, J Indian Geophys Union, 12(3), 131-140.

Montgolfier, J. 2005. Les Espaces Boisés Méditerranéens Situation et Perspectives (Jean de Montgolfier, et al.), Translation book, Alanay, A. DOA Publications No: 38, Tarsus (In Turkish).

Rhinane, H., Hilali, A., Bahi, H., Berrada, A. 2012. Contribution of Landsat TM data for the detection of urban heat islands areas case of Casablanca, Journal of Geographic Information System, 4 (1), Article ID: 17055 , 7 pages DOI:10.4236/jgis.2012.41003

Roy, D.P., Wulder, M.A., Loveland, T.R., Woodcock, C.E., Allen, R.G., Anderson, M.C., Helder, D., Irons, J.R., Johnson, D.M., Kennedy, R., Scambos, T.A., Schaaf, C.B., Schott, J.R., Sheng, Y., Vermote, E.F., Belward, A.S., Bindschadler, R., Cohen, W.B., Gao, F., Hipple, J.D., Hostert, P., Huntington, J., Justice, C.O., Kilic, A., Kovalskyy, V., Lee, Z.P., Lymburner, L., Masek, J.G., McCorkel, J., Shuai, Y., Trezza, R., Vogelmann, J., Wynne, 
Duran, C. (2015). Effects on drought and vegetation of topography in the Tarsus River Basin (Southern Turkey). International Journal of Human Sciences, 12(2), 1853-1866. doi:10.14687/ijhs.v12i2.3370

R.H., and Zhu, Z. 2014. Landsat-8: Science and product vision for terrestrial global change research. Remote Sensing of Environment. 145, 154-172

Sobrino, J. A., Jimenez-Munoz, J. C. and Paolini, L. 2004. Land surface temperature retrieval from LANDSAT TM 5.Remote Sensing of Environment 90, 434-40.

Sengün, M. T., Duran, C., 2008. Effects of geomorphologic units on plant diversity and microclimate: a case study of Kadincik valley, Mersin, Geomorphology Symposium, Canakkale (In Turkish).

Weng, Q., Lu, D., Schubring, J. 2004. Estimation of land surface temperature-vegetation abundance relationship for urban heat island studies. Remote Sensing of Environment, 89, No. 4 pp. 467-483 doi:10.1016/j.rse.2003.11.005

Le-xiang, Q., Hai-shan, C. 2008. Relationship between normalized difference moisture index and land surface temperature. Geographical Research, 27(6): 1358-1367.

Yuan, F., Bauer, M.E. 2007. Comparison of impervious surface area and normalized difference vegetation index as indicators of surface urban heat island effects in Landsat imagery. Remote Sensing of Environment 106, 375-386.

MTA, 2013. General Directorate of Mineral Research and Exploration, Geology maps. Ankara, Turkey. (In Turkish).

GDF, 2013. General Directorate of Forestry, Forest management maps. Ankara, Turkey (In Turkish).

URL 1. http://landsat.usgs.gov/15.05.2015

URL 2. http://landsat.usgs.gov/Landsat8_Using_Product.php/15.05.2015 